\title{
RECREATION: ECONOMIC DEVELOPMENT IMPACT AND SEASONALITY
}

\author{
Christopher Garbacz*
}

The development of recreational centers for the population of major urbancenters of the midcontinent offers a promising potential use of the Ozarks'.. physical resources. ${ }^{1}$

\section{RECREATION IMPACT}

Some poor counties that were almost converted to inland seas by the Corps of Engineers in the early and middle sixties have experienced a surge in economic development because they bridge the gap between rural and urban areas, the reby acting to alleviate an as pect of the rural-to-urban-to-suburban migration problem. As cities and suburbs become more crowded, demand for open space and recreation, notably water-based recreation, grows. These forces tend to work toward an equilibrium of both migration and income ${ }^{2}$ between urban and rural America. While the impact of recreation on the economic base of poor counties may not be strong enough to ove rcome all problems, it should at least be explored, possibly as a partial solution. This is a step in planning to solve recreation and economic development problems for urban and rural areas.

This paper surveys the economic development impact of recreation and leisure activities on a depressed two-county region of Arkansas. ${ }^{3}$ The unique characteristics of the area are that a large water impoundment $(40,000$ acres) was completed in 1963, a growing number of tourists have been attracted to the reservoir and area $(3,039,000$ in 1971 as opposed to 912,000 in 1963) and that a large part of the economic base of the counties in question is in recreation and leisure production. Little growth has occurred because of other productive activities. ${ }^{4}$

The types of activities involved included camping, boating, fishing,skiing, swimming, sightseeing, hiking, and lazing. Some who engage in these activities are much more intensive recreationists or leisurists than others in that theyspend more at play. Also, some types of activities a re more expensive than others. Visitors who own a home (permanent or mobile) near the lake or those who have retired to the area because of the lake are classified as intensive. Those who stay at the luxury inns and those who camp are intensive, though of higher and lower degree. Those who stop at the dam site and the overlook, where President Kennedy dedicated the project, are some of the least intensive visitors usually staying only a few hours and maybe spending no more than the price of a coke or a tank of gas. Therefore, 3, 039, 000 visitors in 1971 is not a hardfigure because of the great divergence in the intensity of visits. What is needed is a classification by intensity of visit.

The two counties have experienced a resurgence in the last ten years. A number of indicators point this up. ${ }^{5}$ Tables 1 and 2 contain some important data illustrating the structural change that has occurred in the two-county region.

*Christopher Garbacz, University of Missouri at Rolla 
It appears that several building booms, some concurrent, some distinct, 6 have stimulated the local economy. From 1960 to 1965, there was a motel building boom with total rooms available near the lake climbing 316.66 percent; from 1965 to 1971 , less than 100 rooms we re added, a $6.98 \%$ increase, even though the number of tourists more than doubled (113 percent). Either excess motel capacity was established in the earlier period or the new visitors are simply passing through, or perhaps they own or rent homes, or maybe they camp. In 1963, man-days camping equalled 82,000, whereas in 1971 it had grown to 770,540 . While campers are not as intensive in theirstay as are motel users who spend an estimated $\$ 30$ per day per family, they still spend an estimated $\$ 18$ per day per family. 7

A continuing building impact has been felt from those constructing vacation homes, and from those who retire to the area, as well as those who live within the area and choose to build and live near the lake. The total value of homes adjacent to the lake now approximates $\$ 30.5$ million.

Table 2 shows the decline in population from 1950 to 1960 which undoubtedly reflected out-migration. The census of 1970 showed an encouraging population increase which probably reflects in-migration because of the increase in opportunities. Per capita personal income has risen faster than the state average in both counties, though Cleburne has a substantial edge. Retail sales have grown very rapidly in Cleburne County but have risen at less than the state average in Van Buren. Bank deposits are up sharply with both counties having about the same percentage gain but with Cleburne controlling 66.5 percent of the total for the two counties. Finally, value added in manufacturing has not seen much rise. However, this final trait is good from one point of view. It strongly argues that recreation is very important to the area because of the paucity of anything else, and it facilitates the development of a strong predictive model for seasonal employment variations related to rerroation.

\section{SEASONALITY}

A significant proportion of the labor force in the two counties, about 25 percent, is tied either directly or indirectly to recreation expenditures associated with the lake. 8 A problem which immediately is evident, however, is seasonality of employment. Several statistical tests have been run to determine the severity of the fluctuations in employment and to determine those variables which appear to "explain" seasonality of employment.

An analysis of variance (one-way classification) was conducted to test the null hypothesis of equal means, $\mathrm{H}_{1}=\mu_{1}=\mu_{2}=\ldots=\mu_{12}$, for monthly data on nonmanufacturing employment. The mean $\mu_{1}$ was computed for nonmanufacturing employment for the month of Januaryover the period 1963-70, $\mu_{2}=$ February over the same period and so forth. Since the computed variance ratio $\mathrm{F}_{11,84}=2.6446>2.47=\mathrm{F} .99 ; 11,84$ the null hypothesis is rejected at the 1 percent level of significance. Seasonality, ${ }^{9}$ for our purposes, is present per the results of the previous test.

A multiple regression was run with the dependent variable being the log of nonmanufacturing employment 10 in Cleburne and Van Buren counties for each month and the independent variable being the log of man-days camping lagged one year $\left(\mathrm{X}_{1}\right)$. 11 The period covered was 1970 and the first quarter of 1971. The purpose was to suggest an explanation for the seasonal fluctuation in nonmanufacturing employment. The fitted equation is 


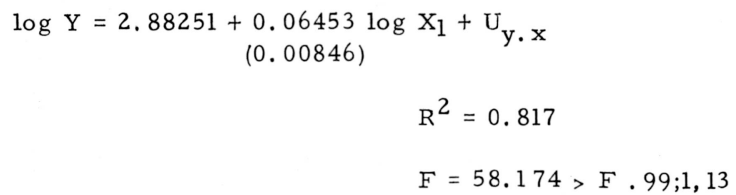

Monthly fluctuations in nonmanufacturing employment a re explained to a large degree by the independent variable (which is significant at the 1 percent level). The reason the regress andwas selected revolves a round the idea of visitor intensity. Camping is a recreation activity that requires more expenditure within the region, 12 especially because of the tendency to stay overnight. It seems logical, therefore, that nonmanufacturing employment would move rather closely with $\mathrm{X}_{1}$ visitation rates. The indication is that there may be excess capacity during some periods of the year. The additional number of campers, and probably other visitors as well, can be serviced by proportionately fewer additional workers indicating that capacity is underutilized over some of the year.

Since the fluctuation in nonmanufacturing employment reflects recreation activity in the area, an attempt to smooth out the fluctuations would involve smoothing out the visitation rates ${ }^{13}$ by increasing visits in the present low season. A diversification of the recreation and leisure opportunities to attract visitors in the present off-season would serve to increase total economic impact while at the same time reducing overall fluctuation of nonmanufacturing employment.

\section{CONCLUSION}

Initial results suggest that with additional data the formulation of a powerful, predictive model may be in the offing. Data over a longer period of time and a wider range of recreation-based counties will tend to reduce the $\mathrm{R}^{2}$ as some additional, preliminary tests suggest. However, the level of significance for $X_{1}$ remains at the 1 percent level for a period as long as 75 months covering the same counties.

Further research in what appears to be a fruitful area is continuing. 
TABLE 1. SELECTED INDICATORS OF THE ECONOMIC IMPACT OF

\begin{tabular}{|c|c|c|c|c|c|c|c|c|c|c|}
\hline & $\underline{1960}$ & 1963 & $\underline{1964}$ & $\underline{1965}$ & 1966 & $\underline{1967}$ & 1968 & 1969 & $\underline{1970}$ & $\underline{1971}$ \\
\hline Tourists $(000)$ & - & 912 & 1400 & 1429 & 1431 & 1631 & 2007 & 2207 & 2742 & 3039 \\
\hline Automobiles (000) & - & 304 & 449 & 505 & 516 & 510 & 614 & 649 & 753 & 829 \\
\hline $\begin{array}{l}\text { Rooms Available } \\
\text { Near Lake }\end{array}$ & 258 & 515 & 821 & 1075 & 1115 & 1145 & 1145 & 1150 & 1150 & 1155 \\
\hline $\begin{array}{l}\text { Private or Recreational } \\
\text { Homes Adjacent to Lake }\end{array}$ & - & 120 & 166 & 262 & 309 & 510 & 760 & 1025 & 1375 & 1650 \\
\hline $\begin{array}{l}\text { Value }(\$ 000) \\
\text { of Above Homes }\end{array}$ & - & 1625 & 2788 & 3801 & 4871 & 8039 & 14148 & 20150 & 27000 & 30500 \\
\hline $\begin{array}{l}\text { Value }(\$ 000) \text { of Non- } \\
\text { Resident Homes }\end{array}$ & - & 629 & 2369 & 3231 & 4140 & 6833 & 9972 & 10500 & 11250 & 11750 \\
\hline $\begin{array}{l}\text { Labor Force Tied } \\
\text { Directly to Lake }\end{array}$ & 17 & 79 & 190 & 250 & 400 & 425 & 435 & 475 & 600 & 625 \\
\hline $\begin{array}{l}\text { Value }(\$ 000) \text { of Out- } \\
\text { door Recreation Equip- } \\
\text { ment Sold Near Lake }\end{array}$ & 10 & 314 & 586 & 626 & 675 & 742 & 809 & 1000 & 1200 & 1560 \\
\hline
\end{tabular}

Source: U.S. Army Engineer District, Little Rock, Corps of Engineers, Financial and Statistical Report Recreational Activities Greers Ferry Reservoir Area 1963-1971, Little Rock: Mimeo, 1964-1972. 
TABLE 2. INDICATORS OF ECONOMIC DEVELOPMENT

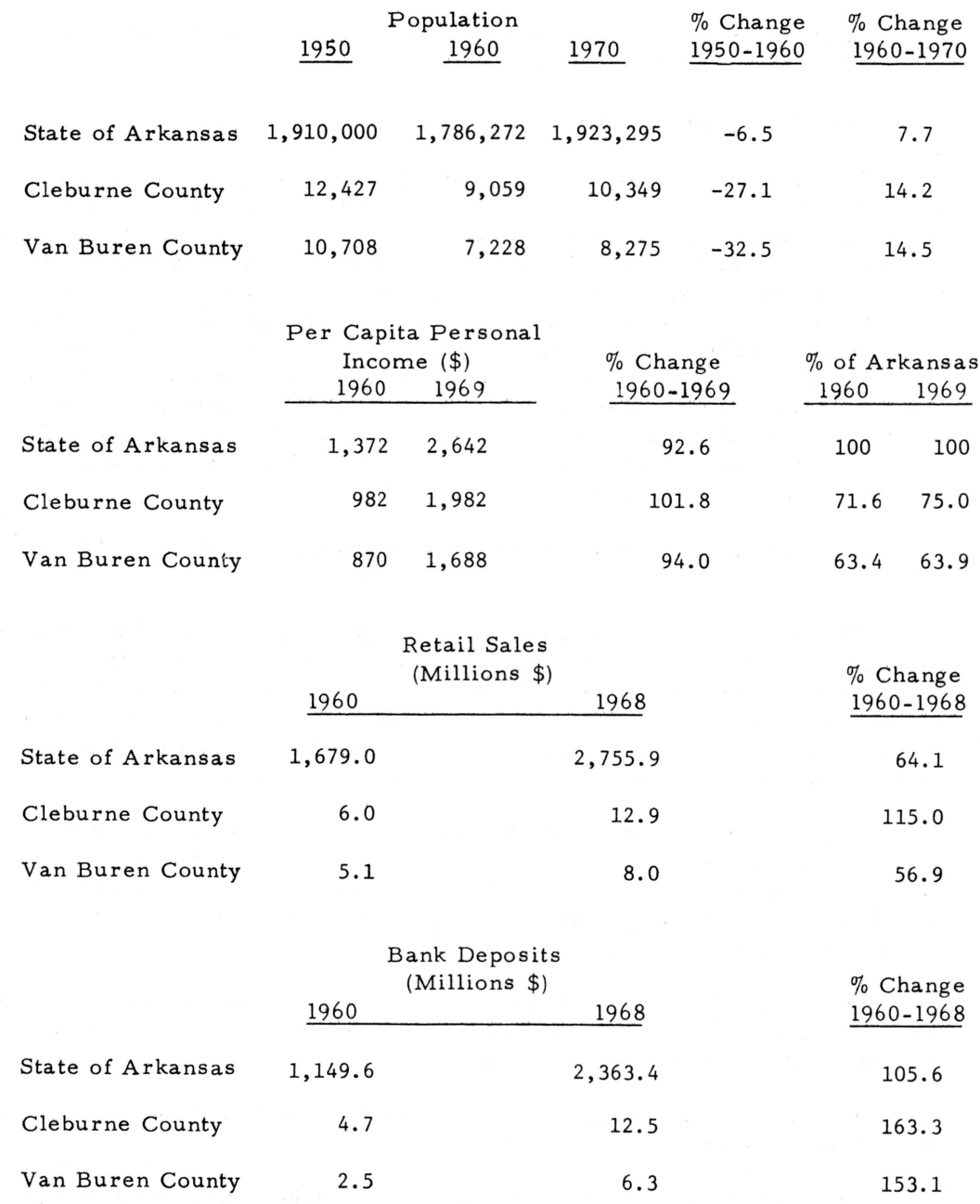

Total Value Added In Manufacturing (Millions \$) 1963 1967

Cleburne County 1.2 1.8 Van Buren County 0.6 b

${ }^{b}$ Withheld to avoid disclosing figures for individual companies.

Source: Industrial Research and Extension Center, University of Arkansas, State and County Economic Data for Arkansas. 


\section{FOOTNOTES}

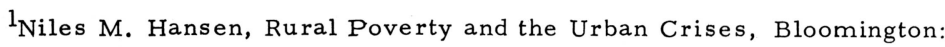
Indiana University Press, 1970, p. 115.

${ }^{2}$ Income includes income of a psychic nature.

${ }^{3}$ Legitimate debate may range over the question of how much development is related to the new-found recreation (export) base and whether the economic impact is plus or minus after all benefits and costs (socialand private) have been netted out. Because of the data available it is difficult to apply a precise measure to this question. However, while recognizing the importance of social costs, this paper does not attempt to treat that aspect of economic development. Also, since most of the argument on recreationrelated employment was presented in an earlier paper, the section on economic-development impact is restricted to a brief survey with the citation of two tables suggestive of the type of economic impact that has occurred. See: Christopher Garbacz, "The Ozarks: Recreation and Economic Development." Land Economics, November 1971, pp. 418-421. 1970 .

${ }^{4}$ Manufacturing employment remained relatively stable from 1964 through

${ }^{5}$ A questionnaire is planned which will be mailed to a random sample of residents of the counties to determine the economic impact of the switch to a recreation economic base. The mailing would occur twice, once during the peak season and once during the low season. This would provide detailed data to answer questions such as whether poor have benefited, how much retirement affects the area, how much commuting goes on, etc.

${ }^{6}$ The first boom came with the construction of the dam and related activities around the reservoir from 1959-1963. This is apparent from the relatively high employment in 1963. Operation and maintenance costs for recreation facilities of the Corps of Engineers has grown from $\$ 27,700$ in 1963 to $\$ 578,100$ in 1971 .

7 Estimates based on surveys by Better Homes and Gardens and National Advertising Agency cited in Parks and Tourism Department, State of Arkansas, Travel Statistics 1964-1970. Mimeo. Undated.

${ }^{8}$ Christopher Garbacz, "The Ozarks: Recreation and Economic Development, " pp. 418-421.

9It should be noted that the fluctuation is at higher levels of overall employment.

${ }^{10}$ Nonmanufacturing employment in most cases would be a rathe $\mathrm{r}$ broad proxy for water-based recreation employment though some of each sub-category of the major category may be related to water-based recreation activities. Five sub-categories a re cited throughout the available data: trade; finance, insurance, and real estate; services; other; and transportation, communications, and utilities. Under any of the headings some employment would be recreation related. However, these groupings a re not published for both counties in a consistent fashion.

${ }^{11}$ Visitation data were gathered by the Corps of Engineers, Little Rock, Arkansas District. 
12 Another measure of intensity might be more appropriate, such as the number of motel rooms used per month. These data a re not available at this time.

${ }^{13}$ There are, of course, other solutions such as bringing in industry that could benefit from the water available. Since one town in one of the counties has contractedwith the Corps of Engineers for the purchase of water and has the right to resell the water, industrial uses are possible. Within the context of this paper though, this possibility is not explored. 